\title{
Effect of familiarity with COVID-19 infection-history of infection or close contact-on outing behaviors when a state of emergency is declared
}

4 Takahiro Mori a, Tomohisa Nagata ${ }^{\text {a }}$, Kazunori Ikegami ${ }^{\mathrm{b}}$, Ayako Hino ${ }^{\mathrm{c}}$, Seiichiro Tateishi ${ }^{\mathrm{d}}$,

5 Mayumi Tsuji ${ }^{\text {e, }}$, Shinya Matsuda ${ }^{\mathrm{f}}$, Yoshihisa Fujino ${ }^{\mathrm{g}}$, Koji Mori ${ }^{\mathrm{a} *}$, for the CORoNaWork

6 project

8 Affiliations:

9 a Department of Occupational Health Practice and Management, Institute of Industrial 10 Ecological Sciences, University of Occupational and Environmental Health, 1-1 Iseigaoka 11 Yahatanishi-ku, Kitakyushu, Fukuoka, 807-8555, Japan

12 b Department of Work Systems and Health, Institute of Industrial Ecological Sciences, 13 University of Occupational and Environmental Health, Japan, 1-1 Iseigaoka Yahatanishi-ku, 14 Kitakyushu, Fukuoka, 807-8555, Japan

${ }^{c}$ Department of Mental Health, Institute of Industrial Ecological Sciences, University of Occupational and Environmental Health, Japan, 1-1 Iseigaoka Yahatanishi-ku, Kitakyushu, Fukuoka, 807-8555, Japan

${ }^{\mathrm{d}}$ Department of Occupational Medicine, School of Medicine, University of Occupational and Environmental Health, Japan, 1-1 Iseigaoka Yahatanishi-ku, Kitakyushu, Fukuoka, 807-8555, Japan

${ }^{\mathrm{e}}$ Department of Environmental Health, School of Medicine, University of Occupational and Environmental Health, Japan, 1-1 Iseigaoka Yahatanishi-ku, Kitakyushu, Fukuoka, 807-8555, Japan

${ }^{\mathrm{f}}$ Department of Public Health, School of Medicine, University of Occupational and Environmental Health, Japan, 1-1 Iseigaoka Yahatanishi-ku, Kitakyushu, Fukuoka, 807-8555, Japan

${ }^{\mathrm{g}}$ Department of Environmental Epidemiology, Institute of Industrial Ecological Sciences, University of Occupational and Environmental Health, Japan, 1-1 Iseigaoka Yahatanishi-ku, Kitakyushu, Fukuoka, 807-8555, Japan

\section{*Correspondence author: Koji Mori, MD, PhD}

Department of Occupational Health Practice and Management, Institute of Industrial Ecological Sciences, University of Occupational and Environmental Health, Japan, 1-1 Iseigaoka, Yahatanishi-ku, Kitakyushu 807-8555, Japan.

5 E-mail: kmori@med.uoeh-u.ac.jp; Tel: +81-93-603-1611; Fax: +81-93-603-2155 
37 Background: Restricting the movement of the public to gathering places and limiting close physical contact are effective measures against COVID-19 infection. In Japan, states of emergency have been declared in specific prefectures to reduce public movement and control COVID-19 transmission. We investigated how familiarity with the COVID-19 infection affected self-restraint related to outing behaviors during state of emergency declarations in 42 Japan.

Methods: A prospective cohort study was conducted among workers aged 20-65 years using data from an internet survey. The baseline survey was conducted on December 22-25, 2020, and a follow-up survey was on February 18-19, 2021. There were 19,941 participants who completed both surveys and were included in the final analysis. We set self-restraint regarding outing behaviors after the second state of emergency was declared in January 2021 as the dependent variable, and levels of familiarity with COVID-19 infection as independent variables. Odds ratios were estimated using multilevel logistic analyses.

Results: Significant differences by familiarity with COVID-19 infection were identified: compared with people without a history of COVID-19 or close contact with cases of confirmed COVID-19, and those whose acquaintances had not been diagnosed with COVID-19, people with a history of COVID-19 did not refrain from most outing behaviors. People with an acquaintance diagnosed with COVID-19 were significantly more likely to refrain from most outing behaviors. There was no significant difference in any outing behavior for people with a history of close contact only.

Conclusions: To maximize the effect of emergency declarations, health authorities should disseminate information for each person in the target population, taking into account potential differences related to the familiarity with the infection.

Key words: familiarity, COVID-19, self-restraint, outing behaviors, emergency declaration 


\section{Introduction}

An effective control measure for coronavirus disease 2019 (COVID-19) infection is to reduce opportunities for people to go to places where people gather or have close physical contact with others [1,2], and the most powerful measure is a nationwide restriction of behavior, the so-called lockdown. The known routes of COVID-19 infection include droplet infection, aerosol infection, and contact infection, so many infections occur in places where people gather or are in close physical contact. Lockdowns have been implemented in many countries during the COVID-19 pandemic with varying degrees of success in terms of strength and duration. In China [3], Italy [4], and France [5], the movement of people in various places and the distance traveled in daily life were significantly reduced after lockdown. In the United States as well, the number of customers visiting retail stores decreased after lockdown measures were implemented [6]. A study using data from 202 countries reported that the reduction in outings due to lockdown reduced the number of newly infected people, especially after 10 days post- declaration, and the effect was maintained until 20 days post-declaration [7].

Japan has also declared a state of emergency to reduce the movement of people and thereby control COVID-19 infections. A total of four states of emergency have been declared due to the epidemic situation of COVID-19; the first was declared to all prefectures, and the second and subsequent were declared only to those prefectures where the infection situation was worsening. The first was from April to May 2020, when the first wave arrived in Japan; the second was from January to March 2021 when the third wave arrived; the third was from April to June 2021; the fourth was from July 2021, when the fourth wave arrived. However, Japan's declarations of a state of emergency did not have penal provisions as did some other countries and were merely requests that citizens refrain from movement and social gatherings [8]. Nonetheless, these requests led to similar effects on reduction of outing behaviors as did such declarations in the United States, which did provide penal provisions [9].

The reason why similar effects were obtained may be that information on the infection situation, such as announcements of measures by the government and daily reports on the number of infected people and deaths, contribute to increased voluntarily restraint on going out, in addition to the intervention effect of the emergency declaration [6,9]. However, because the effect of this information is large, even during periods when a state of emergency is declared, if the number of infected people decreases, the number of people going out increases, and as a result, the number of infections will stop declining [8].

Age and sex have been investigated as factors affecting responses to declarations of a 
state of emergency in Japan and lockdowns in other countries. In Japan, young people and women were reported to have been more responsive to the declarations and more likely to refrain from going out [10]. Similarly, in Europe, young people and women refrained from going out $[11,12]$. Elderly people in Japan were more likely to respond to information such as daily reports on the number of infected people and deaths [10]. In addition, in Japan, the states of emergency were declared in areas where the number of infected people was particularly high, most of which were in major cities, but nearly equivalent effects on refraining from going out were obtained in areas where states of emergency were declared $[9$, 13]. In the United States as well, there was little difference between areas under lockdown and areas not under lockdown in terms of restricting movement [6].

Familiarity with COVID-19 infections may be another factor affecting propensity to restrict movement. The familiarity of infection can be classified into (1) people with a history of infection, (2) people with a history of close contact, and (3) people with acquaintances who have been infected. For people with a history of infection, re-infection is unlikely because of the development of neutralizing antibodies [14,15], so these individuals may be less likely to take measures against infection or refrain from going out in public. Conversely, people with a history of close contact or acquaintances who have been infected may consider themselves to have a high possibility of self-infection, further strengthening their likelihood to take measures against infection and refrain from outing behaviors. However, to our knowledge, these effects have not yet been investigated.

We therefore investigated how familiarity with COVID-19 infection affected self-restraint in outing behaviors when the second state of emergency was declared in Japan in January 2021.

\section{Material and methods}

\subsection{Study design and participants}

This prospective cohort study was undertaken by a research group from the University of Occupational and Environmental Health, Japan, called the Collaborative Online Research on Novel-coronavirus and Work study (CORoNaWork study). This survey was conducted as a self-administrated questionnaire by the internet survey company Cross Marketing Inc. (Tokyo, Japan). The baseline survey was conducted on December 22-25, 2020, and the follow-up survey was on February 18-19, 2021; both periods were during the third wave of the pandemic in Japan. Details of the study protocol have been previously reported [16]. Participants $(n=33,087)$ were aged 20-65 years and employed at the time of the baseline 
131 survey. Respondents to the CORoNaWork study were stratified by cluster sampling according 132 to sex, age, and region of residence. After excluding 6,051 initial subjects who provided 133 invalid responses, we ultimately included 27,036 in the database. These subjects were given a 134 follow-up survey, and 19,941 people responded ( $74 \%$ follow-up rate). The flow diagram is 135 shown in Figure 1. Occupational and Environmental Health, Japan (Approval numbers: R2-079 and R3-006). Informed consent was obtained in the form of the website from all participants.

Figure1. Flow chart of the study participants.

Invalid respondents $n=6051$

Valid respondents

to baseline survey $\mathrm{n}=27036$

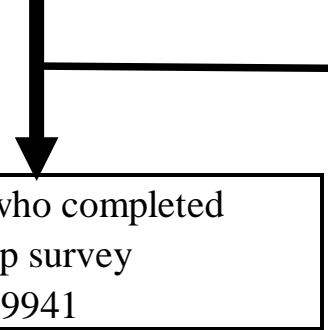

Did not respond $\mathrm{n}=7095$

Respondents who completed

follow-up survey

$\mathrm{n}=19941$

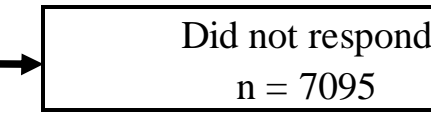


medRxiv preprint doi: https://doi.org/10.1101/2021.08.20.21262364; this version posted August 21, 2021. The copyright holder for this preprint (which was not certified by peer review) is the author/funder, who has granted medRxiv a license to display the preprint in perpetuity.

\subsection{Assessment of outing behaviors}

We identified eight outing behaviors: (1) eating out (4 people or fewer); (2) eating out (5 people or more); (3) gathering with friends and colleagues; (4) day trip; (5) overnight trip (excluding visiting home); (6) visiting home; (7) shopping for daily necessities; and (8) shopping for other than daily necessities. We divided eating out into four people or fewer and five or more to identify any difference based on the number of people, particularly because the Japanese government has emphasized that drinking or dining with five or more people carries a particularly high risk of infection [8]. For each of the eight behaviors, we asked participants in the follow-up survey, "Has your self-restraint changed in response to the second declaration of a state of emergency in January 2021?" Respondents chose one of the following five options: very increased, a little increased, no change, a little decreased, or very decreased. We created a binary variable by defining "a little decreased" or "very decreased" as having self-restraint behavior, and the others as not having self-restraint behavior.

\subsection{Assessment of the familiarity of infection}

In the baseline survey, we asked participants three questions about their familiarity with infection: "Have you ever been infected with COVID-19?", "Have you ever been in close contact with someone with COVID-19?", and "Do you have an acquaintance who has been infected with COVID-19?" Respondents answered each question with "Yes" or "No", and were classified into the four following types: people with a history of COVID-19; people without history of COVID-19 but with a history of close contact with cases of confirmed COVID-19 (hereinafter referred to as people with a history of close contact); people without a history of COVID-19 or close contact with cases of confirmed COVID-19 but who had an acquaintance who had been diagnosed with COVID-19 (hereinafter referred to as people whose acquaintance was diagnosed); and people without history of COVID-19 or close contact with cases of confirmed COVID-19, and who did not have an acquaintance diagnosed with COVID-19 (hereinafter referred to as people without history of COVID-19 or close contact).

\subsection{Assessment of covariates}

Covariates included demographics, socioeconomic factors, job type, and prefectures with and without the second declaration of a state of emergency. Age was expressed as a continuous variable. Education was classified into three categories: junior high or high school, vocational school or college, and university or graduate school. Marital status was classified into three 
medRxiv preprint doi: https://doi.org/10.1101/2021.08.20.21262364; this version posted August 21, 2021. The copyright holder for this preprint

(which was not certified by peer review) is the author/funder, who has granted medRxiv a license to display the preprint in perpetuity.

All rights reserved. No reuse allowed without permission.

categories: married, divorced or widowed, and never married. Equivalent income was classified into four categories: <2.50 million Japanese yen (JPY); 2.50-3.74 million JPY; 3.75-5.24 million JPY; and $\geq 5.25$ million JPY (1 USD was equal to 106.78 JPY, using 2020 conversion rates) [17]. Job type was classified into three categories: mainly desk work, jobs mainly involving interpersonal communication, and mainly physical work. There were 11 prefectures that had the second declaration of a state of emergency, and 36 prefectures without this declaration.

\subsection{Statistical analyses}

Multilevel logistic regression analyses were used to examine the association between familiarity with infection and self-restraint from outing behaviors after the second declaration of a state of emergency. An analysis was performed on each of the eight outing behaviors. We estimated an age-sex adjusted odds ratio (OR) for each (Model 1), then additionally adjusted for education, marital status, equivalent income, and job type (Model 2), along with prefectures with and without the second declaration of a state of emergency (Model 3). A p-value of less than 0.05 was considered statistically significant. All analyses were conducted using Stata Statistical Software (Release 16; StataCorp LLC, College Station, TX, USA).

\section{Results}

Table 1 shows the participant characteristics for each category of familiarity of infection. There were 18,208 people without history of COVID-19 or close contact, 154 people with a history of COVID-19, 141 people with a history of close contact, and 1438 people who had an acquaintance who was diagnosed. The mean age was youngest for people with a history of COVID-19. People without history of COVID-19 or close contact had a lower rate of being married than did other groups. In prefectures with the emergency declaration, there were fewer people without history of COVID-19 or close contact and more people with a history of COVID-19, with a history of close contact, and whose acquaintance was diagnosed than in prefectures without the declaration.

Table 2 shows the association between familiarity with infection and refraining from outing behaviors during declaration of the second state of emergency. In multivariate analysis adjusted for age, sex, education, marital status, equivalent income and job type (Model 2), among people with a history of COVID-19, the odds ratios were significantly lower than people without history of COVID-19 or close contact, for eating out (4 people or less) (OR 0.50), eating out (5 people or more) (OR 0.50), gathering with friends and colleagues (OR 
211 0.41), day trip (OR 0.51), overnight trip (OR 0.49), and shopping other than daily necessities

212 (OR 0.68). There was no significant difference in visiting home or in shopping for daily

213 necessities, but there was a tendency to refrain from visiting home (OR 0.75, p =0.080).

214 Conversely, the odds ratio in people whose acquaintance had been diagnosed was 215 significantly higher for eating out (4 people or fewer) (OR 1.42), eating out (5 people or 216 more) (OR 1.49), gathering with friends and colleagues (OR 1.56), day trip (OR 1.36), 217 overnight trip (OR 1.37), visiting home (OR 1.27), and shopping other than daily necessities 218 (OR 1.32), but there was no significant difference for shopping for daily necessities. People 219 with a history of close contact showed no significant difference in any of the outing behaviors 220 compared with people without history of COVID-19 and close contact. After additional 221 adjustment for prefectures with and without declaration of the second state of emergency 222 (Model 3), the results were similar to those for Model 2. 
medRxiv preprint doi: https://doi.org/10.1101/2021.08.20.21262364; this version posted August 21, 2021. The copyright holder for this preprint (which was not certified by peer review) is the author/funder, who has granted medRxiv a license to display the preprint in perpetuity.

All rights reserved. No reuse allowed without permission.

Table 1. Characteristics of participants

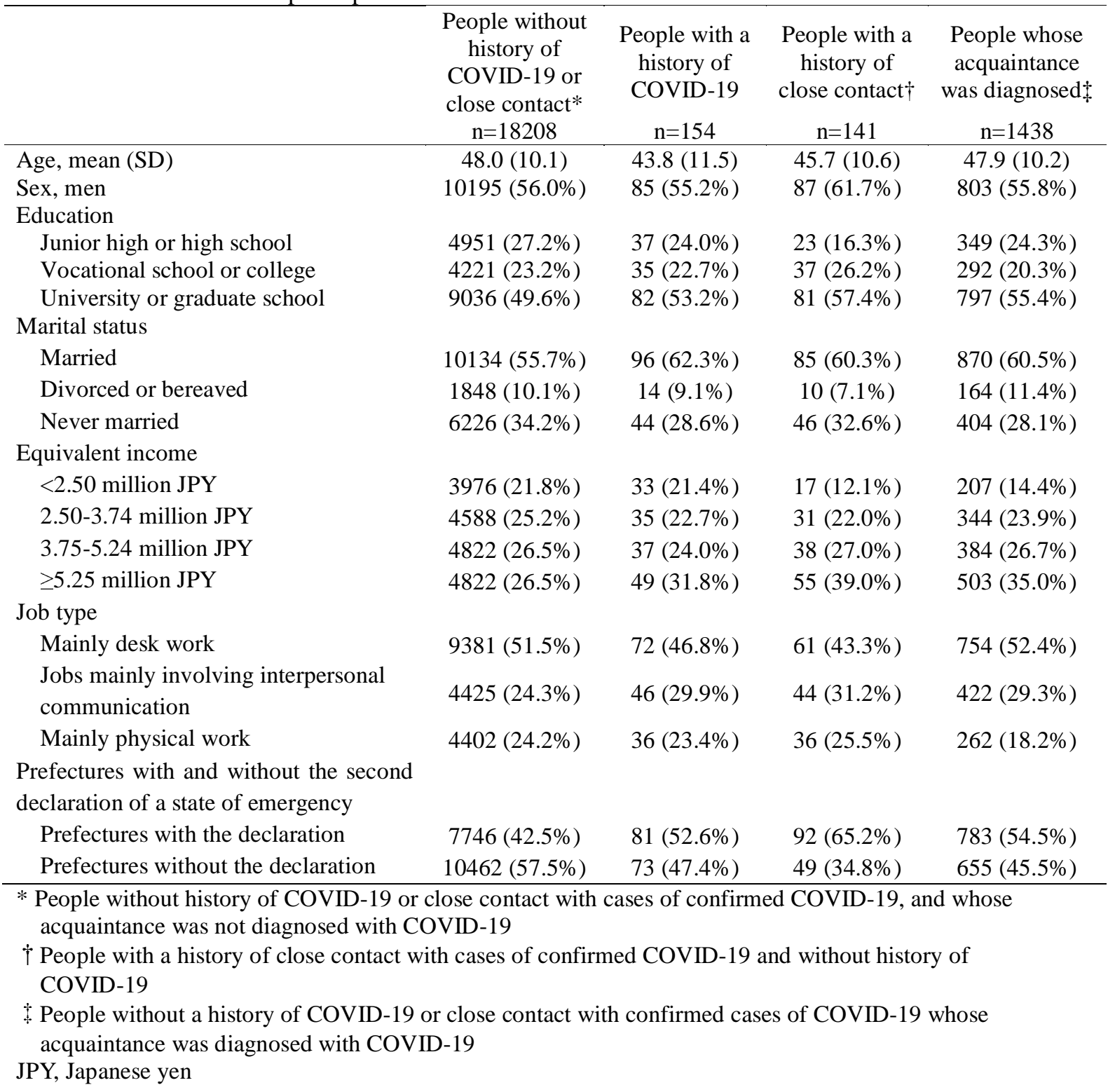


Table 2. Association between familiarity with infection and self-restraint from outing behaviors during the second declaration of a state of emergency

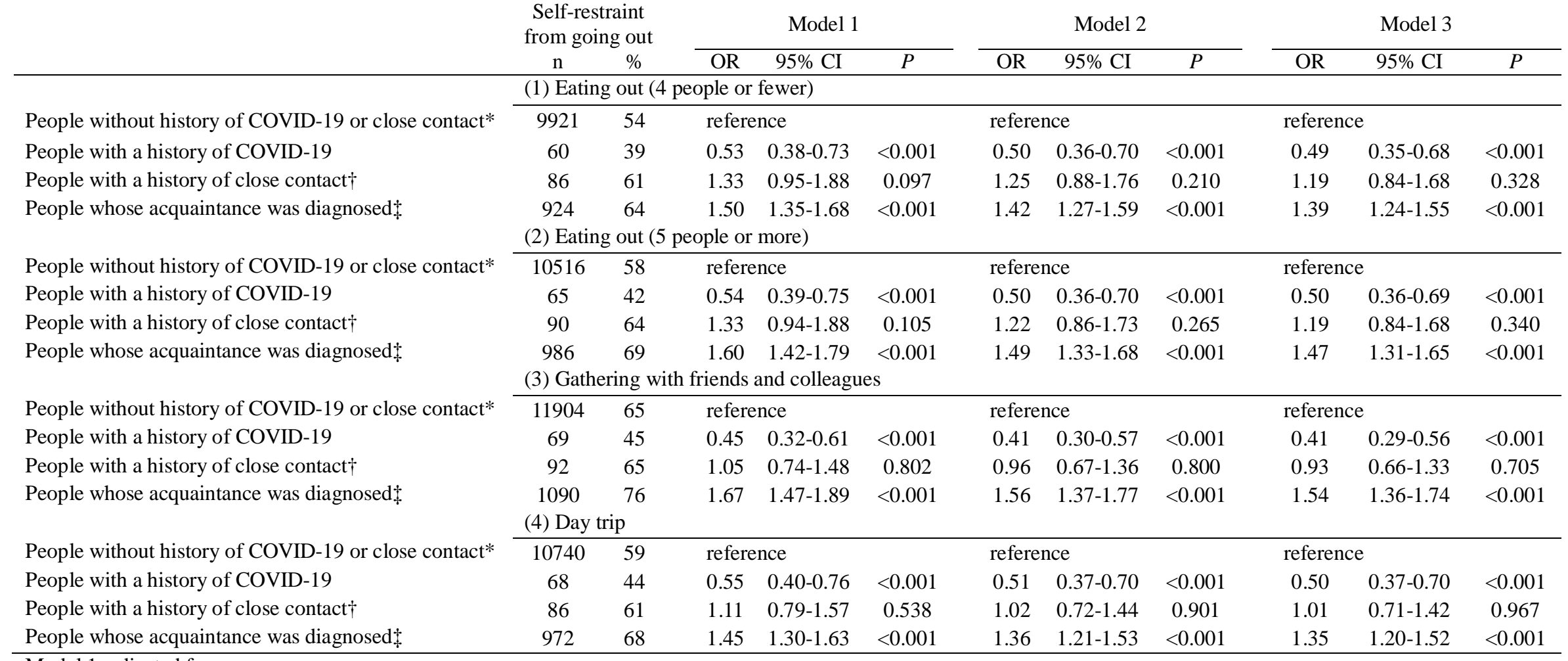

Model 2: Model 1 additionally adjusted for education, marital status, equivalent income and job type

Model 3: Model 2 additionally adjusted for prefectures with and without the second declaration of a state of emergency

* People without history of COVID-19 or close contact with cases of confirmed COVID-19, and whose acquaintance was not diagnosed with COVID-19

$\uparrow$ People with a history of close contact with cases of confirmed COVID-19 and without history of COVID-19

$\$$ People without a history of COVID-19 or close contact with confirmed cases of COVID-19 whose acquaintance was diagnosed with COVID-19 


$$
\text { Self-restrain }
$$

from going out

n $\%$

(5) Overnight

People without history of COVID-19 or close contact*

People with a history of COVID-19

People with a history of close contact $\dagger$

People whose acquaintance was diagnosed $\ddagger$

People without history of COVID-19 or close contact*

People with a history of COVID-19

People with a history of close contact $\dagger$

People whose acquaintance was diagnosed $\ddagger$

People without history of COVID-19 or close contact*

People with a history of COVID-19

People with a history of close contact $\dagger$

People whose acquaintance was diagnosed $\ddagger$

People without history of COVID-19 or close contact*

People with a history of COVID-19

People with a history of close contact $\dagger$

People whose acquaintance was diagnosed $\$$

60 trip (excluding visiting home)

60 reference

$\begin{array}{llll}69 & 45 & 0.54 & 0.39-0.74\end{array}$

$90 \quad 64$

$994 \quad 69$

(6) Visiting home

853947

$\begin{array}{ccc}8539 & 47 & \text { reference } \\ 65 & 42 & 0.82\end{array}$

$\begin{array}{cc}75 & 53 \\ 785 & 55\end{array}$

$0.82 \quad 0.59-1.13$

$1.30 \quad 0.93-1.81$

$\begin{array}{ll}1.30 & 0.93-1.81 \\ 1.36 & 1.22-1.52\end{array}$

(7) Shopping for daily necessities

\begin{tabular}{|c|c|c|c|c|c|c|c|c|c|c|}
\hline 4980 & 27 & \multicolumn{3}{|c|}{ reference } & \multicolumn{3}{|c|}{ reference } & \multicolumn{3}{|c|}{ reference } \\
\hline 53 & 34 & 1.35 & $0.97-1.89$ & 0.078 & 1.32 & $0.94-1.85$ & 0.106 & 1.31 & $0.93-1.83$ & 0.121 \\
\hline 45 & 32 & 1.26 & $0.88-1.80$ & 0.213 & 1.24 & $0.86-1.77$ & 0.247 & 1.21 & $0.84-1.73$ & 0.300 \\
\hline 437 & 29 & 1.10 & $0.98-1.24$ & 0.108 & 1.08 & $0.96-1.22$ & 0.185 & 1.07 & $0.95-1.21$ & 0.253 \\
\hline \multicolumn{11}{|c|}{ (8) Shopping other than daily necessities } \\
\hline 7973 & 44 & \multicolumn{3}{|c|}{ reference } & \multicolumn{3}{|c|}{ reference } & \multicolumn{2}{|c|}{ reference } & \\
\hline 55 & 36 & 0.71 & $0.51-0.99$ & 0.044 & 0.68 & $0.49-0.95$ & 0.025 & 0.67 & $0.48-0.94$ & 0.020 \\
\hline 61 & 43 & 1.01 & $0.72-1.42$ & 0.933 & 0.97 & $0.69-1.36$ & 0.844 & 0.94 & $0.67-1.32$ & 0.707 \\
\hline 741 & 52 & 1.37 & $1.23-1.53$ & $<0.001$ & 1.32 & $1.18-1.47$ & $<0.001$ & 1.30 & $1.16-1.45$ & $<0.001$ \\
\hline
\end{tabular}

240 Model 1: adjusted for sex, age

241 Model 2: Model 1 additionally adjusted for education, marital status, equivalent income and job type

Model 3: Model 2 additionally adjusted for prefectures with and without the second declaration of a state of emergency

* People without history of COVID-19 or close contact with cases of confirmed COVID-19, and whose acquaintance was not diagnosed with COVID-19

$\uparrow$ People with a history of close contact with cases of confirmed COVID-19 and without history of COVID-19

t People without a history of COVID-19 or close contact with confirmed cases of COVID-19 whose acquaintance was diagnosed with COVID-19 
medRxiv preprint doi: https://doi.org/10.1101/2021.08.20.21262364; this version posted August 21, 2021. The copyright holder for this preprint (which was not certified by peer review) is the author/funder, who has granted medRxiv a license to display the preprint in perpetuity.

All rights reserved. No reuse allowed without permission.

\section{4. Discussion}

We examined the impact of familiarity with infection on self-restraint from outing behaviors during the second declaration of a state of emergency. People with a history of COVID-19 reported significantly lower self-restraint from outing behavior than did people without a history of COVID-19 or close contact, except regarding shopping for daily necessities. People with an acquaintance who had been diagnosed were significantly more likely to refrain from outing behavior except for shopping for daily necessities. There was no significant difference in any outing behavior for people with a history of close contact with COVID-19 cases. Similar results were observed after adjustment for prefectures with and without the declaration.

The results of people with a history of COVID-19 and people with acquaintances who were diagnosed were similar to what we had expected. It has been shown that risk perception for infection is involved in infection prevention behavior [18-20]. Risk perception for infection includes perceptions of the possibility and severity of infection [21]. The association between risk perception and preventive behavior was also reported in various countries during the $2009 \mathrm{H} 1 \mathrm{~N} 1$ influenza epidemic [22-28].

The reason why people with a history of COVID-19 did not refrain from outing behaviors may result from their perception that they were less likely to be infected with COVID-19 again and their perception of the severity of the infection. At the time of this survey, the number of infected people in Japan was less than $0.5 \%$ of the total population [8]. This infection rate was so low that infected people might have thought that they were unlucky even once infected, and infected persons often acquire neutralizing antibodies, so they might also have thought that re-infection was unlikely to occur $[14,15]$. In addition, because past experiences have been reported to be less associated with concerns about voluntary risk behavior [24], a COVID-19 diagnosis might not lead to refraining from outing behavior that may have caused them to become infected in the past or increase their risk of infection. As for the perception of severity, if their infection was relatively mild or asymptomatic, they may have had perceived the severity of COVID-19 infection to be lesser. Accordingly, even when a state of emergency was declared, there was no change in self-restraint from outing behaviors.

Conversely, people who had an acquaintance who was diagnosed were considered to have increased risk perception. A survey of Japanese people has shown that the risk to oneself is underestimated compared with the risk to society as a whole [29]. If a close acquaintance was infected or even became seriously ill, it is probable that the risk perception to oneself 
increased, leading to refraining from outing behavior.

For people with a history of close contact, the results were different from our assumptions, and no significant difference was observed in any of outing behaviors. The reasons for this result are not clear from this survey, but it is possible that there were both those who refrained from outing behaviors and those who did not. In Japan, epidemiological surveys are conducted by health centers on each infected person, and close contacts are identified. After certification, close contacts undergo a real-time reverse transcription-polymerase chain reaction (rt-PCR) test to check for infection and are quarantined at home for 14 days, even if negative [16]. As mentioned above, people with a history of close contact felt close to the infection, so it is probable that they may have adopted the same behaviors as people whose acquaintance was diagnosed. Conversely, it seems that there were a number of people who did not refrain from outing behavior. Some people may think that they have already been infected because of the possibility of false negatives even if the rt-PCR test is negative, or from the experience of being isolated at home for 14 days. In addition, many people are recognized as close contacts as a result of their family members living together being infected [30-32], and often make decisions about outing behaviors with their family members. These people therefore may have not refrained from outing behaviors like people with a history of COVID-19.

Regarding the specific aspects of outing behaviors, for shopping for daily necessities, neither people with a history of COVID-19 nor people whose acquaintance was diagnosed showed a significant difference compared with people without history of COVID-19 and close contact. This may be because shopping for daily necessities is a daily activity necessary for daily life, unlike other outing behaviors. Regarding eating out, similar results were seen in eating out with four people or fewer and with five or more, suggesting that they have a similar perception of the risk of infection.

After adjusting for prefectures with and without declaration (Model 3), the results did not change. This suggests that people in prefectures with and without declarations showed similar reactions when the state of emergency was declared. Previous studies in Japan and the United States have investigated the difference in the degree of self-restraint from outing behavior between the areas with declarations and areas without, with results were similar to those in this study [6,9]. In Japan, the prefectures with a declaration included major cities, and people living in prefectures without a declaration often go to or pass through the major cities. In addition, in many prefectures without a declaration, the number of newly infected people increased during the same period [8]. Information on the number of infected people and 
314 deaths in the prefectures with the declaration was also reported daily on television and the 315 internet. This information may have influenced the self-restraint of outing behavior in the 316 prefectures without the declaration because in addition to the intervention effect of the 317 declaration of the state of emergency, it has been shown that the information effect is large as well [9].

It is necessary to pay attention not only to age and sex factors that have already been investigated [10-12], but also to the familiarity of infection. Since it has been shown that the information effect is large [9], it is necessary to disseminate information that makes the infection more familiar, and also that refraining from outing behaviors is beneficial to society as a whole, including the national health care system. In addition, individual risk preference is known to be influenced by the decision-making of surrounding individuals [34], and it will be easier to make the choice to go out if many people go out when self-restraint is requested. It is therefore necessary to provide appropriate information to people with a history of COVID-19, such as the possibility of re-infection and the effects of new variants of COVID-19 virus [35].

There are several limitations to this study. First, we conducted an internet survey, which includes the possibility of selection bias. However, sampling was balanced by sex, age, occupation, and area of residence at the start of the study to reduce the potential for bias. Second, the follow-up survey was conducted two months after the baseline survey. We classified the familiarity of infection using data from the baseline survey, so there may have been new people infected in the intervening two months. However, the ratio in each category implies that the number of newly applicable people was very small, and unlikely to significantly affect the results. Third, the outcome of interest in this survey was a decrease in self-restraint, but those who were not originally outing at all before the second state of emergency was declared were included in the group who did not respond to self-restraint. However, the movement of people during the non-declaration period does not appear to have been significantly suppressed compared with before the COVID-19 epidemic [13]. This implies that there would have been few people in this category who did not go out at all during the non-declaration period.

\section{Conclusion}

Our results show that the level of self-restraint from outing behaviors due to the declaration of a state of emergency differs depending on a subject's familiarity with COVID-19 infection. When declaring a state of emergency, in order to maximize the effect of the declaration, 
medRxiv preprint doi: https://doi.org/10.1101/2021.08.20.21262364; this version posted August 21, 2021. The copyright holder for this preprint

(which was not certified by peer review) is the author/funder, who has granted medRxiv a license to display the preprint in perpetuity.

All rights reserved. No reuse allowed without permission.

account the differences due to the familiarity of the infection.

\section{Acknowledgements}

The current members of the CORoNaWork Project, in alphabetical order, are as follows: Dr. Yoshihisa Fujino (present chairperson of the study group), Dr. Akira Ogami, Dr. Arisa Harada, Dr. Ayako Hino, Dr. Hajime Ando, Dr. Hisashi Eguchi, Dr. Kazunori Ikegami, Dr. Kei Tokutsu, Dr. Keiji Muramatsu, Dr. Koji Mori, Dr. Kosuke Mafune, Dr. Kyoko Kitagawa, Dr. Masako Nagata, Dr. Mayumi Tsuji, Ms. Ning Liu, Dr. Rie Tanaka, Dr. Ryutaro Matsugaki, Dr. Seiichiro Tateishi, Dr. Shinya Matsuda, Dr. Tomohiro Ishimaru, and Dr. Tomohisa Nagata. All members are affiliated with the University of Occupational and Environmental Health, Japan.

\section{Funding}

This study was supported and partly funded by the research grant from the University of Occupational and Environmental Health, Japan (no grant number); Japanese Ministry of Health, Labour and Welfare (H30-josei-ippan-002, H30-roudou-ippan-007, 19JA1004, 20JA1006, 210301-1, and 20HB1004); Anshin Zaidan (no grant number), the Collabo-Health Study Group (no grant number), and Hitachi Systems, Ltd. (no grant number) and scholarship donations from Chugai Pharmaceutical Co., Ltd. (no grant number)

\section{Disclosure statement}

The authors declare no conflict of interest.

\section{Authors' contributions}

$\mathrm{TM}$; data analysis and writing the manuscript, TN; creating the questionnaire, review of manuscript, and advice on interpretation, HA, AH, ST, MT, and SM; review of manuscripts, and advice on interpretation, YF; overall survey planning, creating the questionnaire, review of manuscripts, and advice on interpretation, KM; data analysis, drafting the manuscript, review of manuscripts, and advice on interpretation, and final approval of the version to be submitted by all authors 
medRxiv preprint doi: https://doi.org/10.1101/2021.08.20.21262364; this version posted August 21, 2021. The copyright holder for this preprint (which was not certified by peer review) is the author/funder, who has granted medRxiv a license to display the preprint in perpetuity.

All rights reserved. No reuse allowed without permission.

\section{References}

1. Honein MA, Christie A, Rose DA, Brooks JT, Meaney-Delman D, Cohn A, et al. Summary of Guidance for Public Health Strategies to Address High Levels of Community Transmission of SARS-CoV-2 and Related Deaths, December 2020. MMWR Morb Mortal Wkly Rep 2020;69:1860-7. https://doi.org/10.15585/mmwr.mm6949e2.

2. Would Health Organization. Transmission of SARS-CoV-2: implications for infection prevention precautions. https://www.who.int/news-room/commentaries/detail/transmission-of-sars-cov-2-implicat ions-for-infection-prevention-precautions [accessed 16 Aug 2021].

3. Fang H, Wang L, Ynag Y. Human mobility restrictions and the spread of the Novel Coronavirus (2019-nCoV) in China. Journal of Public Economics 2020;191:104272. https://doi.org/10.1016/j.jpubeco.2020.104272.

4. Pepe E, Bajardi P, Gauvin L, Privitera F, Lake B, Cattuto C, et al. COVID-19 outbreak response, a dataset to assess mobility changes in Italy following national lockdown. Sci Data 2020;7:3-9. https://doi.org/10.1038/s41597-020-00575-2.

5. Pullano G, Valdano E, Scarpa N, Rubrichi S, Colizza V. Evaluating the effect of demographic factors, socioeconomic factors, and risk aversion on mobility during the COVID-19 epidemic in France under lockdown: a population-based study. Lancet Digit Heal 2020;2:e638-49. https://doi.org/10.1016/S2589-7500(20)30243-0.

6. Goolsbee A, Syverson C. Fear, lockdown, and diversion: Comparing drivers of pandemic economic decline 2020. J Public Econ 2021;193:104311. https://doi.org/10.1016/j.jpubeco.2020.104311.

7. Alfano V, Ercolano S. The Efficacy of Lockdown Against COVID-19: A Cross-Country Panel Analysis. Appl Health Econ Health Policy 2020;18:509-17. https://doi.org/10.1007/s40258-020-00596-3.

8. Cabinet Secretariat. COVID-19 Information and Resources. https://corona.go.jp/en/dashboard/ [accessed 16 Aug 2021].

9. Watanabe T, Yabu T. Japan's Voluntary Lockdown 2020. PLOS ONE 2021;16:e0252468. https://doi.org/10.1371/journal.pone.0252468.

10. Watanabe T, Yabu T. Japan's voluntary lockdown: further evidence based on age-specific mobile location data. Japanese Econ Rev 2021:1-38. https://doi.org/10.1007/s42973-021-00077-9.

11. Caselli, Francesca, Francesco Grigoli, Damiano Sandri, and Antonio Spilimbergo. Mobility under the COVID-19 pandemic: Asymmetric effects across gender and age. IMF 
Working Paper, WP/20/282.

12. Andersen, Asger Lau, Emil Toft Hansen, Niels Johannesen, and Adam Sheridan. Pandemic, shutdown and consumer spending: Lessons from Scandinavian policy responses to COVID-19. arXiv preprint 2020. arXiv:2005.04630.

13. Cabinet Secretariat. COVID-19 Information and Resources: The amount of people flowing between prefectures and their changes [In Japanese]. https://corona.go.jp/dashboard/pdf/flow_20210712.pdf [accessed 16 Aug 2021].

14. Hansen CH, Michlmayr D, Gubbels SM, Mølbak K, Ethelberg S. Assessment of protection against reinfection with SARS-CoV-2 among 4 million PCR-tested individuals in Denmark in 2020: a population-level observational study. Lancet 2021;397:1204-12. https://doi.org/10.1016/S0140-6736(21)00575-4.

15. Yamayoshi S, Yasuhara A, Ito M, Akasaka O, Nakamura M, Nakachi I, et al. Antibody titers against SARS-CoV-2 decline, but do not disappear for several months. EClinicalMedicine 2021;32:100734. https://doi.org/10.1016/j.eclinm.2021.100734.

16. Fujino Y, Ishimaru T, Eguchi H, Tsuji M, Tateishi S, Ogami A, et al. Protocol for a nationwide Internet-based health survey in workers during the COVID-19 pandemic in 2020. J UOEH 2021;43:217-225. doi:10.7888/juoeh.43.217.

17. Organisation for Economic Co-operation and Development. Exchange rates (indicator). [accessed 16 Aug 2021]. doi: 10.1787/037ed317-en

18. Brewer NT, Weinstein ND, Cuite CL, Herrington JE. Risk Perceptions and Their Relation to Risk Behavior. Ann Behav Med 2004;27:125-30. https://doi.org/10.1207/s15324796abm2702_7.

19. Weinstein ND. Testing four competing theories of health-protective behavior. Health Psychol 1993;12:324-33. https://doi:10.1037//0278-6133.12.4.324.

20. Sutton SR. Social-psychological approaches to understanding addictive behaviours: attitude-behaviour and decision-making models. $\mathrm{Br} \mathrm{J}$ Addict 1987;82:355-70. https://doi:10.1111/j.1360-0443.1987.tb01492.x.

21. Brewer NT, Chapman GB, Gibbons FX, Gerrard M, McCaul KD, Weinstein ND. Meta-analysis of the relationship between risk perception and health behavior: The example of vaccination. Heal Psychol 2007;26:136-45. https://doi.org/10.1037/0278-6133.26.2.136.

22. Jones JH, Salathe M. Early assessment of anxiety and behavioral response to novel swine-origin influenza A(H1N1). PLoS One 2009;4:e8032. https://doi.org/10.1371/journal.pone.0008032. 
medRxiv preprint doi: https://doi.org/10.1101/2021.08.20.21262364; this version posted August 21, 2021. The copyright holder for this preprint (which was not certified by peer review) is the author/funder, who has granted medRxiv a license to display the preprint in perpetuity.

All rights reserved. No reuse allowed without permission.

23. Chor JSY, Ngai KLK, Goggins WB, Wong MCS, Wong SYS, Lee N, et al. Willingness of Hong Kong healthcare workers to accept pre-pandemic influenza vaccination at different WHO alert levels: Two questionnaire surveys. BMJ 2009;339:b3391. https://doi.org/10.1136/bmj.b3391.

24. Rubin GJ, Amlôt R, Page L, Wessely S. Public perceptions, anxiety, and behaviour change in relation to the swine flu outbreak: Cross sectional telephone survey. BMJ 2009;339:b2651. https://doi.org/10.1136/bmj.b2651.

25. Seale H, Heywood AE, McLaws ML, Ward KF, Lowbridge CP, Van D, et al. Why do I need it? I am not at risk! Public perceptions towards the pandemic (H1N1) 2009 vaccine. BMC Infect Dis 2010;10. https://doi.org/10.1186/1471-2334-10-99.

26. Lau JTF, Griffiths S, Choi KC, Tsui HY. Avoidance behaviors and negative psychological responses in the general population in the initial stage of the H1N1 pandemic in Hong Kong. BMC Infect Dis 2010;10. https://doi.org/10.1186/1471-2334-10-139.

27. Lau JTF, Griffiths S, Choi K chow, Lin C. Prevalence of preventive behaviors and associated factors during early phase of the H1N1 influenza epidemic. Am J Infect Control 2010;38:374-80. https://doi.org/10.1016/j.ajic.2010.03.002.

28. Setbon M, Raude J. Factors in vaccination intention against the pandemic influenza A/H1N1. Eur J Public Health 2010;20:490-4. https://doi.org/10.1093/eurpub/ckq054.

29. Inamasu T, Horiguchi I, Marui E. Vulnerability and risk perception to infectious diseases of Japanese [In Japanese]. Journal of health and welfare statistics 2013;60:40-44.

30. Koh WC, Naing L, Chaw L, Rosledzana MA, Alikhan MF, Jamaludin SA, et al. What do we know about SARS-CoV-2 transmission? A systematic review and meta-analysis of the secondary attack rate and associated risk factors. PLoS One 2020;15: e0240205. https://doi.org/10.1371/journal.pone.0240205.

31. Miyahara R, Tsuchiya N, Yasuda I, Ko YK, Furuse Y, Sando E, et al. Familial Clusters of $\begin{array}{llll}\text { Coronavirus. } & \text { Emerg } & \text { Infect }\end{array}$ https://doi.org/10.3201/eid2703.203882.

32. National Institute of Infectious Diseases and Tuberculosis and Infectious Diseases Control Division, Ministry of Health, Labour and Welfare. Positive rate by basic genus and contact location among close contacts with coronavirus infection [In Japanese]. IASR 2021;42:104-106.

33. Centers for Disease Control and Prevention. Running Essential Errands. https://www.cdc.gov/coronavirus/2019-ncov/daily-life-coping/essential-goods-services.ht $\mathrm{ml}$ [accessed 16 Aug 2021]. 
medRxiv preprint doi: https://doi.org/10.1101/2021.08.20.21262364; this version posted August 21, 2021. The copyright holder for this preprint (which was not certified by peer review) is the author/funder, who has granted medRxiv a license to display the preprint in perpetuity.

All rights reserved. No reuse allowed without permission.

34. Chung D, Christopoulos GI, King-Casas B, Ball SB, Chiu PH. Social signals of safety and risk confer utility and have asymmetric effects on observers' choices. Nat Neurosci 2015;18:912-6. https://doi.org/10.1038/nn.4022.

35. Centers for Disease Control and Prevention. SARS-CoV-2 Variant Classifications and Definitions. https://www.cdc.gov/coronavirus/2019-ncov/variants/variant-info.html [accessed 16 Aug 2021]. 